\title{
1-Methylcyclopropene Application and Modified Atmosphere Packaging Affect Ethylene Biosynthesis, Fruit Softening, and Quality of 'Tegan Blue' Japanese Plum During Cold Storage
}

\author{
Ahmad Sattar Khan ${ }^{1}$ and Zora Singh ${ }^{2,3}$ \\ Curtin Horticulture Research Laboratory, Muresk Institute, Faculty of Science and Engineering, \\ Curtin University of Technology, GPO Box U 1987, Perth 6845, Western Australia, Australia
}

\begin{abstract}
ADDITIONAL INDEX WORDS. 1-aminocyclopropane-1-carboxylic acid, exo-polygalacturonase, endo-polygalacturonase, pectin esterase, endo-1,4- $\beta$-D-glucanase, ascorbic acid, total antioxidants, Prunus salicina

Abstract. This research was carried out to extend the postharvest storage of japanese plum (Prunus salicina Lindl. cv. Tegan Blue), which has a short shelf life limiting its export potential. The effects of $1.0 \mu L \cdot L^{-1} 1$-methylcyclopropene (1-MCP) and modified atmosphere packaging (MAP), alone or in combination, on quality of mature japanese plum fruit during storage $\left(0 \pm 1^{\circ} \mathrm{C}\right.$ and $90 \% \pm 5 \%$ relative humidity) were investigated. The activities of enzymes of ethylene biosynthesis [1-aminocyclopropane-1-carboxylic acid synthase (ACS), 1-aminocyclopropane-1-carboxylic acid oxidase (ACO), and 1-aminocyclopropane-1-carboxylic acid (ACC) content] and those of cell wall-associated enzymes [exo-polygalacturonase (exo-PG), endo-polygalacturonase (endo-PG), pectin esterase (PE), and endo-1,4- $\beta$ D-glucanase (EGase)] were also measured. 1-MCP-treated fruit stored in normal atmosphere or in MAP had lower ACC content and inhibited ethylene production with reduced ACS and ACO activities compared with fruit stored in MAP and in normal atmosphere. Similarly, 1-MCP-treated fruit, stored either in normal atmosphere or in MAP, were firmer with reduced exo-PG, endo-PG, PE, and EGase activities compared with fruit stored in MAP and in normal atmosphere. During storage as well as during ripening, fruit stored in MAP exhibited a higher rate of respiration compared with other treatments. MAP exacerbated the effect of 1-MCP in reduction of ethylene production and fruit softening. 1-MCP application in combination with MAP after 5 and 7 weeks of storage delayed the fruit ripening by 10 and 8 days in contrast with control fruit, respectively. During storage, and as well as in ripe fruit, weight loss was reduced in fruit stored in MAP either with or without 1-MCP application. Control fruit and 1-MCP-treated fruit, stored in a normal atmosphere or in MAP, had the same values for the following parameters: chromaticity value $L^{*}, C^{*}$, and hue angle, titratable acidity, and concentrations of soluble solids, ascorbic acid, and total antioxidants. In conclusion, 1-MCP application in combination with MAP can be used effectively to reduce the ethylene biosynthesis and fruit softening during cold storage and to extend the storage life up to 7 weeks followed by $8 \mathrm{~d}$ of ripening without any adverse effects on the quality of ripe fruit.
\end{abstract}

The short shelf life of japanese plum (Prunus salicina Lindl.) and european plum (Prunus domestica L.) fruit limits its export through sea freight. At $1{ }^{\circ} \mathrm{C}$, japanese plum can be stored for only 3 to 5 weeks (Navarro et al., 2005). Different techniques to extend the postharvest storage life of various japanese plum and european plum cultivars that have been tested include preharvest calcium application (Plich et al.,

Received for publication 18 May 2007. Accepted for publication 16 Jan. 2008. We are grateful to Professors W.B. McGlasson (University of Western Sydney), C. Watkins (Cornell University, New York), and H. Behboudian (Massey University, New Zealand) for critically reviewing this manuscript. A.S. Khan acknowledges the financial support of an International Postgraduate Research Scholarship from Curtin University of Technology and from Higher Education Commission of Pakistan for providing partial support for Ph.D. studies; and the University of Agriculture Faisalabad, Pakistan, for granting study leave during this period. We thank Professor A.A. Kader, University of California at Davis, for providing the protocol for estimation of total antioxidants and Dr. S. Lurie, Agricultural Research Organization, The Volcani Center, Bet Dagan, Israel, for providing the protocol for estimation of fruit softening enzymes. Casuarina Valley Orchards, Manjimup, Western Australia, is acknowledged for providing the fruit and BioTechnologies for Horticulture Inc., Waterboro, SC, for providing EthylBlock ${ }^{\mathrm{TM}}$ as a gift sample for the experiments.

${ }^{1}$ Former Ph.D. student.

${ }^{2}$ Associate Professor in Horticulture.

${ }^{3}$ Corresponding author. E-mail: Z.Singh@curtin.edu.au.
2002); postharvest heat treatment (Serrano et al., 2004); preor postharvest application of polyamines (Serrano et al., 2003), aminoethoxyvinylglycine (Jobling et al., 2003), and 1-methylcyclopropene (1-MCP) (Khan and Singh, 2007; Watkins, 2006); edible coating (Navarro et al., 2005); cold storage (Robertson et al., 1991); controlled atmosphere storage (Wang and Vestrheim, 2003); and modified atmosphere (MA) storage (Turk and Ozkurt, 1994). However, the available information is inconclusive and sporadic.

Fruit softening is an important attribute associated with quality of japanese plum and european plum fruit. Fruit softening involves compositional and structural changes in cell wall carbohydrates as a result of activities of cell wall enzymes (Fischer and Bennett, 1991). Pectins, hemicelluloses, and celluloses undergo depolymerization and structural modifications during fruit softening (Chin et al., 1999). Enzymes that are associated with fruit softening include polygalacturonase (PG), pectin esterase (PE), cellulase, and $\beta$-galacturonase (Fischer and Bennett, 1991). In papaya (Carica papaya L.), it has been reported that combination of MA packaging (MAP) and low temperature retarded the fruit firmness with decreased and suppressed activities of PG, PE, and $\beta$-galacturonose enzymes (Lazan et al., 1993) as well as ethylene biosynthesis enzymes (Latifah et al., 1997). 
We were interested in the effects of MAP and application of 1-MCP on japanese plum fruit quality, including its effects on dietary antioxidants that may play a role in human health (Huang et al., 2005). MAP has been reported to extend storage life of various climacteric and nonclimacteric fruit such as sweet cherry (Prunus avium L.) (Petracek et al., 2002), peach [Prunus persica (L.) Bastch.] (Fernandez-Trujillo et al., 1998), and european plum (Turk and Ozkurt, 1994) with variable results on extending storage life and maintaining fruit quality. However, depending on storage conditions and type of polyethylene film used under MA storage, off-flavor and off-odors associated with anaerobic respiration may accumulate and reduce fruit quality (Petracek et al., 2002).

$1-\mathrm{MCP}$ is a gaseous compound that binds irreversibly to ethylene receptors and thereby prevents ethylene-dependent response (Blankenship and Dole, 2003). Extensive research has been conducted on the use of 1-MCP to reduce ethylene production, fruit softening, and to extend storage and shelf life of climacteric fruit, including both japanese plum and european plum (Abdi et al., 1998; Khan and Singh, 2004; Watkins, 2006). Application of 1-MCP in combination with MAP has been reported to delay fruit ripening and extend the postharvest life of banana (Musa acuminata Colla.) and mango (Mangifera indica L.) (Jiang and Joyce, 2000; Jiang et al., 1999). No research work has been reported on the effects of MAP alone and MAP in combination with 1-MCP in extending storage life, regulations of ethylene biosynthesis, fruit softening, and quality parameters such as levels of ascorbic acid and total antioxidants. We hypothesized that 1-MCP in combination with MAP might be more effective in reducing ethylene production, fruit softening, and maintaining fruit quality compared with 1-MCP and MAP alone. These observations prompted us to investigate the role of 1-MCP alone and in combination with MAP in the regulation of ethylene biosynthesis and fruit softening enzymes as well as fruit quality during low-temperature storage and in ripe 'Tegan Blue' japanese plum fruit after low-temperature storage.

\section{Materials and Methods}

\section{Plant materials and fruit}

Nineteen-year-old 'Tegan Blue' japanese plum trees grafted on myrobalan (Prunus cerasifera Ehrh.) rootstock at Casuarina Valley Orchard, Manjimup (lat. 34 $15^{\prime} \mathrm{S}$, long. $116^{\circ} 09^{\prime} \mathrm{E}$ ) in the southwest region of Western Australia (WA) were selected for the experiments. Experimental trees planted in north-south row direction ( $4.25 \mathrm{~m}$ between rows and $2 \mathrm{~m}$ within rows) were trained as a palmette. Fruit of uniform size, free from visual symptoms of disease or blemishes, were harvested at commercial maturity [rate of $\mathrm{C}_{2} \mathrm{H}_{4}$ production $=0.003 \pm 0.001$ $\mu \mathrm{mol} \cdot \mathrm{kg}^{-1} \cdot \mathrm{h}^{-1}$, rate of $\mathrm{CO}_{2}$ production $=0.56 \pm 0.02$ $\mathrm{mmol} \cdot \mathrm{kg}^{-1} \cdot \mathrm{h}^{-1}$, soluble solids concentrations $(\mathrm{SSC})=16.3 \% \pm$ $0.9 \%$, and firmness $=60.3 \pm 2.6 \mathrm{~N}]$ on 8 Mar. 2006 .

Expt. 1: Effects of 1-methylcyclopropene or modified atmosphere packaging alone and in combination on ethylene biosynthesis, fruit softening, and fruit quality during low-temprature storage

Fruit were subjected to various treatments, including: 1) control, 2) $\left.1.0 \mu \mathrm{L} \cdot \mathrm{L}^{-1} 1-\mathrm{MCP}, 3\right) \mathrm{MAP}$ only, and 4) $1.0 \mu \mathrm{L} \cdot \mathrm{L}^{-1}$ $1-\mathrm{MCP}$ in combination with MAP. Fruit were kept in hermitically sealed plastic drums $(68 \mathrm{~L})$ and $1.0 \mu \mathrm{L} \cdot \mathrm{L}^{-1} 1-\mathrm{MCP}$ was maintained by injecting the required amount through a rubber septum following the method of Lalel et al. (2003). 1-MCP was obtained from EthylBlock powder (0.43\% a.i. 1-MCP; Bio-
Technologies for Horticulture, Waterboro, SC). Fruit were treated with 1 -MCP for $24 \mathrm{~h}$ at $20 \pm 1{ }^{\circ} \mathrm{C}$. To apply MAP, fruit were packed in LifeSpan (AMCOR Packaging, Ptv. Ltd., Melbourne, Australia) polyethylene bags $(710 \mathrm{~cm}$ long $\times 500 \mathrm{~cm}$ wide $\times$ $30 \mu \mathrm{m}$ thick), commercially used for storage of japanese plums and european plums during low temperature in WA. Bags were sealed after $4 \mathrm{~h}$ storage at $0 \pm 1{ }^{\circ} \mathrm{C}$, when the temperature of fruit and the storage room had reached the equilibrium. After the previously described treatments, fruit were stored for $60 \mathrm{~d}$ at $0 \pm$ $1{ }^{\circ} \mathrm{C}$ and $90 \% \pm 5 \%$ relative humidity $(\mathrm{RH})$. Fruit samples were taken on days $0,15,30,45$, and 60 of storage to determine ethylene production, respiration rate, fruit firmness, weight loss, SSC, titratable acidity (TA), SSC : TA ratio, levels of ascorbic acid and total antioxidants, activities of ethylene biosynthesis, and fruit softening enzymes. A two-factor (treatments and storage period) factorial design was used for the experiment. All treatments were replicated three times with six fruit as an experimental unit for each parameter studied.

Expt. 2: Effects of 1-methylcyclopropene or modified atmosphere packaging alone and in combination on quality of ripe fruit after 5 and 7 weeks of low-temperature storage

For the second experiment, the same four treatments were applied as for the first experiment and the fruit were stored at $0 \pm 1{ }^{\circ} \mathrm{C}$ and $90 \% \pm 5 \% \mathrm{RH}$. After 5 and 7 weeks of storage, ethylene production and respiration rate were recorded daily during the fruit ripening period at $20 \pm 1{ }^{\circ} \mathrm{C}$. However, fruit quality parameter such as weight loss, SSC, TA, SSC : TA ratio, fruit skin and pulp color, levels of ascorbic acid, and total antioxidants were determined at the fully ripe stage (easting soft).

RESPIRATION RATE. One fruit (in duplicate) per experimental unit was sealed in an airtight jar $(1 \mathrm{~L})$ fitted with a rubber septum for $1 \mathrm{~h}$ at room temperature $\left(20 \pm 1^{\circ} \mathrm{C}\right)$. The respiration rate was measured as $\mathrm{CO}_{2}$ production by injecting $2-\mathrm{mL}$ gas samples from the headspace into an infrared gas analyser (Servomex, Gas Analyser, Analyser Series 1450; Servomex Ltd., East Sussex, UK).

Ethylene Production. To determine the ethylene production, 1-mL gas samples were taken from the headspace of the same jar used for respiration rate and were injected into a gas chromatograph (6890 N Network GC system; Agilent Technologies, Palo Alto, CA) fitted with a 2-m-long stainless steel column (Porapak-Q, $3.175 \mathrm{~mm}$, mesh size 80/100; Supelco, Bellefonte, PA) and a flame ionization detector. Ethylene production during cold storage and during japanese plum fruit ripening was determined as described by Khan and Singh (2007).

ACTIVITIES OF ETHYLENE BIOSYNTHESIS ENZYMES AND 1AMINOCYCLOPROPANE-1-CARBOXYLIC ACID CONTENT IN PULP TISSUES. Activities of 1-aminocyclopropane-1-carboxylic acid synthase (ACS) and 1-aminocyclopropane-1-carboxylic acid oxidase (ACO) enzymes as well as 1-aminocyclopropane-1carboxylic acid (ACC) content from pulp tissue were determined as described by Khan and Singh (2007).

Fruit Firmness. An electronic pressure tester (model EPT-1 pressure tester; Lake City Technical Products, Kelowna, BC, Canada) fitted with an $8-\mathrm{mm}$ spherical tip was used to determine fruit firmness. A small slice of fruit skin was removed and firmness was recorded from both sides of individual fruit. Means were expressed as Newtons.

ACTIVITIES OF FRUIT SOFTENING ENZYMES IN PULP TISSUES. Activities of exo-polygalacturonase (exo-PG), endo-polygalacturonase (endo-PG), pectin esterase (PE), and endo-1,4- $\beta$-D-glucanase 
(EGase) were determined from fruit pulp tissues as described by Khan and Singh (2007).

Protein determination. Protein from fruit pulp tissue was determined using the method of Bradford (1976).

Fruit Color. Hunterlab ColorFlex $45^{\circ} / 0^{\circ}$ Spectrophotometer (HunterLab ColorFlex; Hunter Associates, Reston, VA) was used to measure the changes in fruit color parameters, including chromaticity values $\mathrm{L}^{*}, \mathrm{a}^{*}$, and $\mathrm{b}^{*}$ in skin and pulp of fruit after 5 and 7 weeks of storage and during fruit ripening. Measurements were taken at opposite sides of each fruit using the head of $15-\mathrm{mm}$ diameter. For measuring changes in pulp color, a thin slice of skin $(3 \mathrm{~mm})$ was removed and color parameters were measured. The chroma value $\left(\mathrm{C}^{*}\right)$ and hue angle $\left(\mathrm{h}^{\circ}\right)$ were calculated from chromaticity values $\mathrm{a}^{*}$ and $\mathrm{b}^{*}$ as reported earlier by McGuire (1992).

SOLUBLE SOLIDS CONCENTRATIONS, TITRATABLE ACIDITY, AND SOLUBLE SOLIDS CONCENTRATIONS:TITRATABLE ACIDITY RATIO. TO determine the SSC of fruit juice, a digital refractometer (AtagoPalette PR 101; Atago Co., Tokyo) was used and SSC was expressed as percent soluble solid. To determine the TA, juice was titrated against $0.1 \mathrm{~N} \mathrm{NaOH}$ using phenolphthalein as an indicator to $\mathrm{pH} 8.2$ and was expressed as percent malic acid. SSC : TA ratio was calculated by dividing SSC with the corresponding TA value.

AsCORBIC ACID. Ascorbic acid concentration from fruit pulp was determined following the method of Malik and Singh (2005) with some modifications. Pulp samples (5 g) were homogenized in a glass pestle and mortar using $300 \mathrm{mg}$ white quartz sand $(-50+70$ mesh; Sigma Aldrich, Sydney, Australia) with $20 \mathrm{~mL}(6 \%)$ metaphosphoric acid solution containing $0.18 \%$ disodium salt of ethylene diamine tetra-acetic acid. After homogenization, the content was centrifuged at $3186 g_{n}$ for $10 \mathrm{~min}$, and $400 \mu \mathrm{L}$ supernatant was mixed with $200 \mu \mathrm{L}$ (3\%) metaphosphoric acid, $1.4 \mathrm{~mL}$ distilled water, and $200 \mu \mathrm{L}$ diluted Folin's reagent $(5 \mathrm{~mL}$ distilled water : $1 \mathrm{~mL}$ Folin's reagent, by volume). An ultraviolet/visible spectrophotometer (model 6405; Jenway Ltd., Felsted, UK) was used to measure the absorbance of mixed sample after $10 \mathrm{~min}$ at $760 \mathrm{~nm}$ using 2-mL disposable plastic cuvettes. Ascorbic acid concentration was calculated against $100 \%$ ascorbic acid standard curve.

Weight Loss. Weight loss percent was determined by following the formula: $(A-B) / A \times 100$, in which $A$ is the fruit weight just before storage and $B$ was the fruit weight after storage period.

Total antioxidants. The level of total antioxidants in pulp tissue during fruit ripening was estimated by using the method of Brand-Williams et al. (1995).

Statistical analysis. The data were subjected to analysis of variance (ANOVA) using Genstat (release 9.1; Lawes Agricultural Trust, Rothamsted Experimental Station, Rothamsted, UK) by using two-way ANOVA including treatments and storage period. The effects of various treatments were assessed within ANOVA and Fisher's least significant differences were calculated following a significant $(P \leq 0.05) \mathrm{F}$ test. All the assumptions of analysis were checked to ensure validity of statistical analysis.

\section{Results}

RESPIRATION RATE. Fruit stored in MAP exhibited a rapid increase in respiration rate during storage as well as during ripening of fruit that were stored for 5 and 7 weeks (Figs. 1A

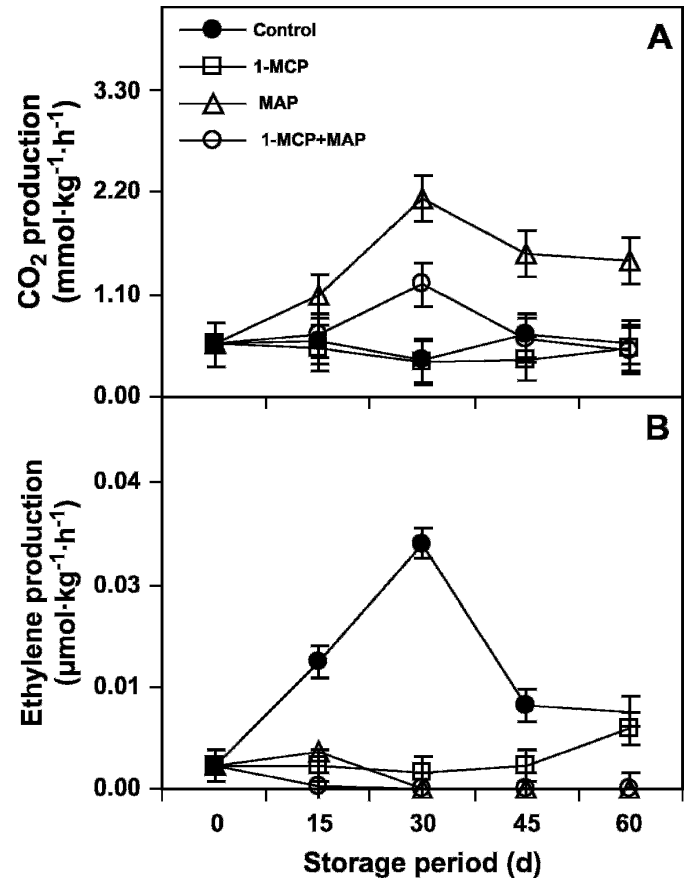

Fig. 1. Effects of postharvest application of 1-methylcyclopropene (1-MCP) and modified atmosphere packaging (MAP) alone or in combination $(+)$ on $(\mathbf{A})$ respiration rate and $(\mathbf{B})$ ethylene production during low-temperature storage in 'Tegan Blue' japanese plum $(\mathrm{n}=3$, three replications). Vertical bars represent SE. Least significant difference (LSD) $(P \leq 0.05)$ for respiration rate: treatments $(\mathrm{T})=0.33$, storage period $(\mathrm{SP})=0.37, \mathrm{~T} \times \mathrm{SP}=0.73$. LSD $(P \leq 0.05)$ for ethylene production: $\mathrm{T}=0.003, \mathrm{SP}=0.002, \mathrm{~T} \times \mathrm{SP}=0.006$.

and 2). The respiration rate of 1-MCP plus MAP-treated fruit increased after $15 \mathrm{~d}$ of storage and peaked on day $30 \approx 43 \%$ lower than fruit stored in MAP alone and control. Fruit treated with 1-MCP and stored in air did not show any rise in respiration throughout the storage period. After 5 weeks of storage, fruit stored in MAP exhibited $72 \%$ higher respiration rate than other treatments (Fig. 2A). Lowest respiration rate was recorded in 1-MCP-treated fruit compared with fruit stored in MAP, with or without 1-MCP treatment, and that of control fruit. On day 1 of fruit ripening, after 7 weeks of storage, 1MCP-treated fruit showed 50\% lower respiration rate than fruit stored in MAP either with or without 1-MCP treatment and control fruit (Fig. 2B). Fruit stored in MAP exhibited a fast increase in their respiration rate during fruit ripening and exhibited respiratory climacteric on day 10 of fruit ripening after 7 weeks of storage $\approx 28 \%, 38 \%$, and $47 \%$ higher than the highest respiration rate of 1-MCP-treated fruit stored in MAP, control fruit, and 1-MCP-treated fruit, respectively.

ETHYLENE PRODUCTION AND ETHYLENE BIOSYNTHESIS ENZYMEs. During low temperature storage, 1-MCP and MAP treatments significantly inhibited the ethylene production in 'Tegan Blue' japanese plum (Fig. 1B). Control fruit exhibited an ethylene peak on day 30 of storage and later ethylene production decreased from day 45 to day 60 . In the second experiment, fruit treated with 1-MCP and stored in MAP for 5 or 7 weeks exhibited reduced and delayed ethylene production during fruit ripening (Fig. 3). 1-MCP and MAP treatments significantly reduced the activities of ACS and ACO enzymes and as well as ACC content in pulp tissues during storage period. Reduction was more pronounced in 1-MCP-treated fruit 


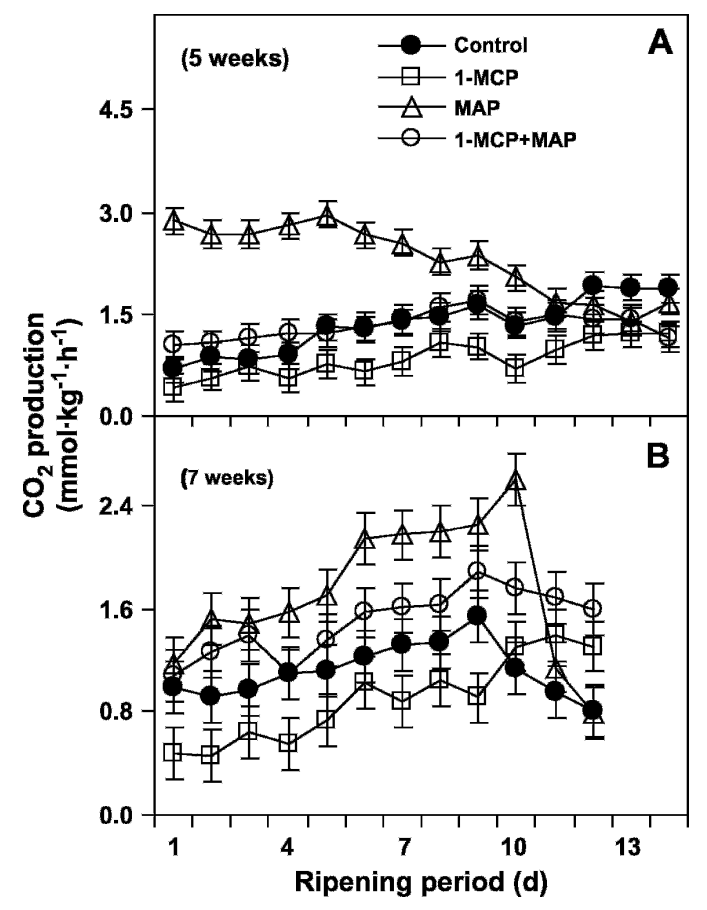

Fig. 2. Effects of postharvest application of 1-methylcyclopropene (1-MCP) and modified atmosphere packaging (MAP) alone or in combination $(+)$ on respiration rate during fruit ripening in 'Tegan Blue' japanese plum stored for 5 and 7 weeks $(n=3$, three replications). Vertical bars represent SE. Least significant difference (LSD) $(P \leq 0.05)$ for 5 weeks: treatments $(\mathrm{T})=0.14$, ripening period $(\mathrm{RP})=0.27, \mathrm{~T} \times \mathrm{RP}=0.54$. $\mathrm{LSD}(P \leq 0.05)$ for 7 weeks: $\mathrm{T}=$ $0.16, \mathrm{RP}=0.27, \mathrm{~T} \times \mathrm{RP}=0.54$.

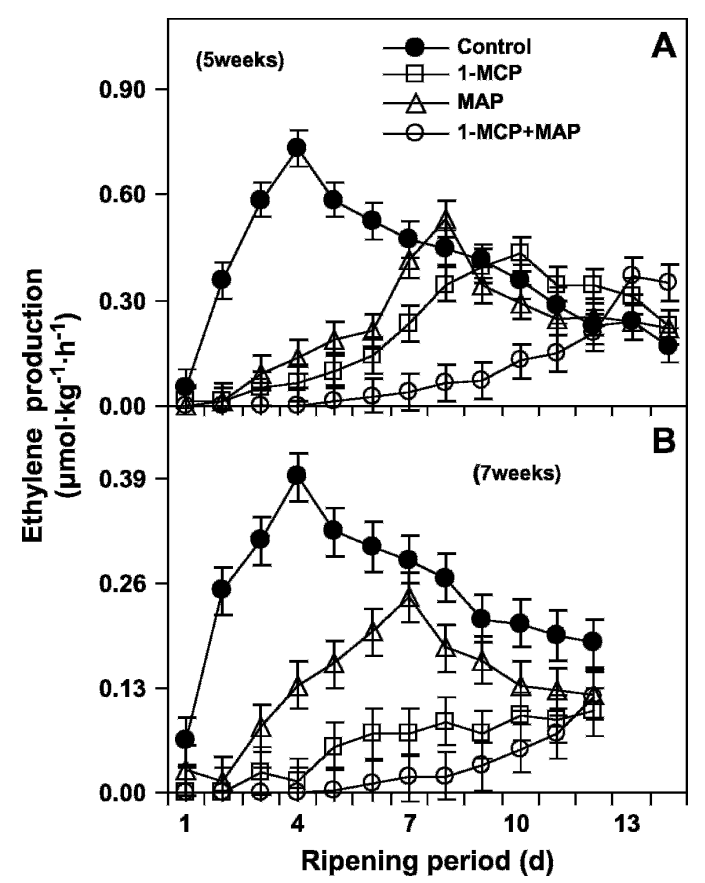

Fig. 3. Effects of postharvest application of 1-methylcyclopropene (1-MCP) and modified atmosphere packaging (MAP) alone or in combination $(+)$ on ethylene production during fruit ripening in 'Tegan Blue' japanese plum stored for 5 and 7 weeks (n $=3$, three replications). Vertical bars represent SE. Least significant difference (LSD) $(P \leq 0.05)$ for 5 weeks: treatments $(\mathrm{T})=$ 0.03 , ripening period $(\mathrm{RP})=0.06, \mathrm{~T} \times \mathrm{RP}=0.11$. LSD $(P \leq 0.05)$ for 7 weeks: $\mathrm{T}=0.03, \mathrm{RP}=0.05, \mathrm{~T} \times \mathrm{RP}=0.11$. stored in MAP (Fig. 4), which shows that MAP exacerbates the effect of 1-MCP in the inhibition of ethylene production.

Fruit SOFTENING AND FRUIT SOFTENING ENZYMES. 1-MCPtreated fruit stored in normal atmosphere or in MAP exhibited significantly higher fruit firmness during storage and in ripe fruit as compared with MAP and control fruit (Figs. 5 and $8 \mathrm{~A}$ ). After $45 \mathrm{~d}$ storage at $0 \pm 1{ }^{\circ} \mathrm{C}, 1$-MCP-treated fruit stored either in MAP or in normal atmosphere showed $42 \%$ and $51 \%$ reduction in fruit firmness compared with fruit stored in normal atmosphere and in MAP, respectively. 1-MCP-treated fruit stored for 5 weeks exhibited higher fruit firmness $(23.1 \mathrm{~N})$ followed by 1-MCP-treated fruit stored in MAP $(22.3 \mathrm{~N})$ as compared with all other treatments (Fig. 8A). Activities of exo$\mathrm{PG}$, endo-PG, $\mathrm{PE}$, and EGase were inhibited during the storage period in fruit treated with 1-MCP and stored either in normal atmosphere or in MAP (Fig. 6). Lowest exo-PG activity during the storage period was determined in pulp tissue of fruit treated with 1-MCP and stored in MAP. On day 60 of storage, pulp tissue of fruit treated with 1-MCP and stored in MAP exhibited

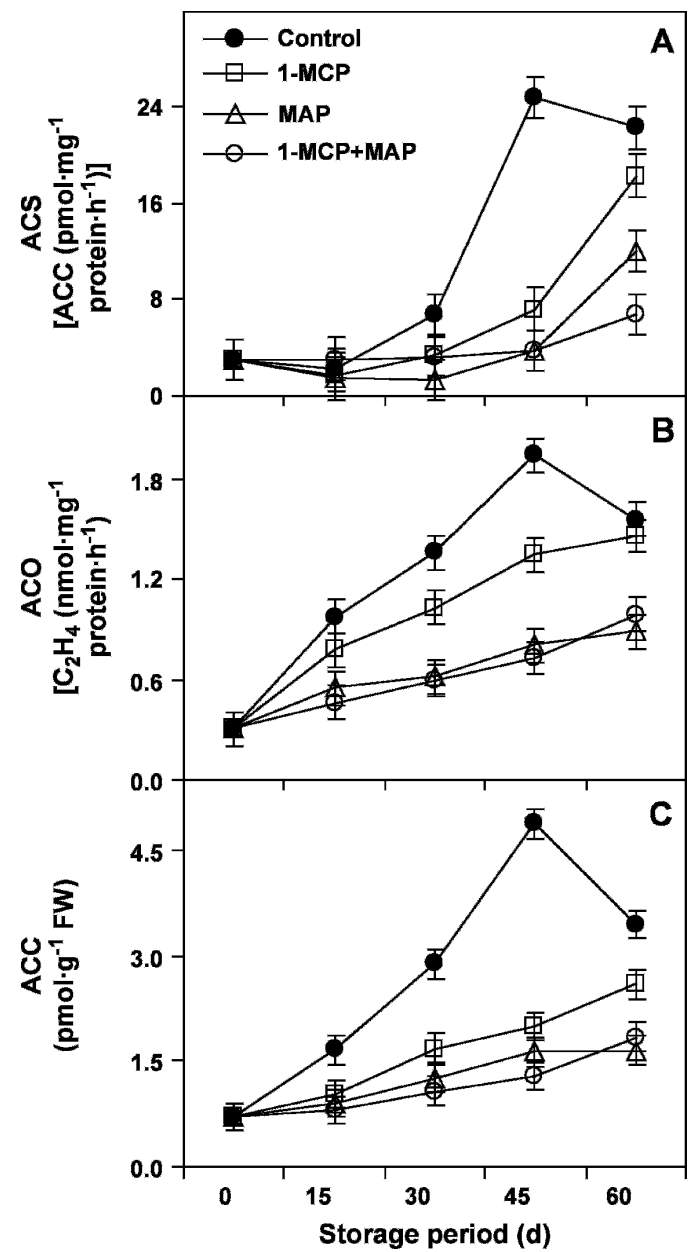

Fig. 4. Effects of postharvest application of 1-methylcyclopropene (1-MCP) and modified atmosphere packaging (MAP) alone or in combination $(+)$ on activities of (A) 1-aminocyclopropane-1-carboxylic acid synthase (ACS), (B) 1-aminocyclopropane-1-carboxylic acid oxidase (ACO) enzymes, and (C) 1aminocyclopropane-1-carboxylic acid (ACC) content during low-temperature storage in pulp tissues of 'Tegan Blue' japanese plum $(n=3$, three replications). Vertical bars represent SE. Least significant difference (LSD) $(P \leq 0.05)$ for ACS: treatments $(\mathrm{T})=2.22$, storage period $(\mathrm{SP})=2.48, \mathrm{~T} \times \mathrm{SP}$ $=4.97$. $\mathrm{LSD}(P \leq 0.05)$ for ACO: $\mathrm{T}=0.1, \mathrm{SP}=0.11, \mathrm{~T} \times \mathrm{SP}=0.23 . \mathrm{LSD}(P \leq$ 0.05 ) for ACC content: $\mathrm{T}=0.24, \mathrm{SP}=0.26, \mathrm{~T} \times \mathrm{SP}=0.53$. 


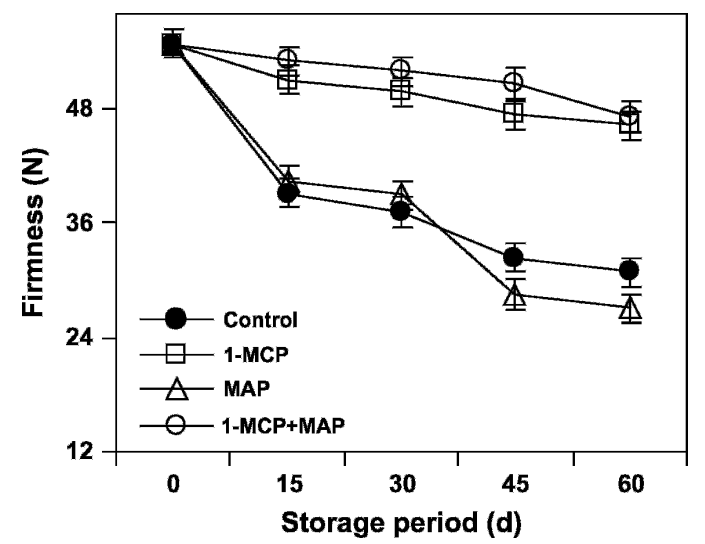

Fig. 5. Effects of postharvest application of 1-methylcyclopropene (1-MCP) and modified atmosphere packaging (MAP) alone or in combination $(+)$ on fruit firmness during low-temperature storage in 'Tegan Blue' japanese plum $(\mathrm{n}=$ 18, three replications, six fruit per replication). Vertical bars represent SE. Least significant difference $(P \leq 0.05)$ for fruit firmness: treatments $(\mathrm{T})=1.9$, storage period $(\mathrm{SP})=2.12, \mathrm{~T} \times \mathrm{SP}=4.24$.

$57 \%, 51 \%$, and $15 \%$ reduction in activity of exo-PG enzyme in contrast to MAP, control, and 1-MCP-treated fruit, respectively (Fig. 6A). Similarly, during storage, 1-MCP-treated fruit stored either in MAP or in normal atmosphere slowed the activity of endo-PG enzyme as compared with pulp tissues of fruit stored in normal atmosphere and in MAP (Fig. 6B). Activities of PE and EGase enzymes in the fruit stored in MAP and in normal atmosphere increased with increased storage period, whereas 1MCP-treated fruit stored either with or without MAP did not show any significant increase in the activities of PE and EGase enzymes during the 60-d storage period (Fig. 6C-D).

WeIGHT LOSS AND DELAY IN FRUIT RIPENING. As expected, control and 1-MCP-treated fruit exhibited a continuous rise in weight loss during the storage period as compared with fruit stored in MAP either with or without 1-MCP application. Highest weight loss was recorded in control fruit on day 60 $\approx 32 \%, 92 \%$, and $96 \%$ higher as compared with 1-MCP-treated, MAP, and fruit treated with 1-MCP and stored in MAP, respectively (Fig. 7). In ripe fruit, weight loss was also reduced in MAP alone or in combination with 1-MCP application compared with other treatments. After 5 and 7 weeks of lowtemperature storage, at the ripe stage, weight loss was highest in control fruit $(6 \%$ and $7 \%)$ followed by $1-\mathrm{MCP}$-treated fruit (5\% and 6.5\%) as compared with other treatments (Fig. 8B). The effects of 1-MCP and MAP in delaying fruit ripening on 'Tegan Blue' japanese plum were synergistic. After 5 and 7 weeks of low-temperature storage, 1-MCP-treated fruit stored in MAP delayed the fruit ripening by 10 and $8 \mathrm{~d} \approx 2$-fold more than their independent effects as compared with control fruit, respectively (Fig. 8C).

SOLUbLe SOLIDS CONCENTRATIONS, TITRATABLE ACIDITY, AND SOLUBLE SOLIDS CONCENTRATIONS : TITRATABLE ACIDITY RATIO. During the first $15 \mathrm{~d}$ of storage, all treatments showed a reduction in SSC and later on 1-MCP-treated fruit stored either in normal atmosphere or in MAP and control fruit exhibited a rise in SSC (Fig. 9A). Fruit stored in MAP showed lowest SSC during storage, in contrast to other treatments, and on day 60 , SSC of fruit stored in MAP was $16 \%, 17 \%$, and $21 \%$ lower than 1-MCP-treated fruit stored either in MAP or in normal atmosphere and control fruit, respectively. TA in all treatments during the first $15 \mathrm{~d}$ of storage increased slightly and later decreased (Fig. 9B). Rate of decrease in TA was quick in fruit stored in MAP compared with other treatments. Fruit stored in MAP showed $55 \%, 64 \%$, and $63 \%$ lower TA on day 60 in contrast to control and fruit treated with 1-MCP and stored either in MAP or in normal atmosphere, respectively. All treatments showed a slightly decreased SSC : TA ratio up to $15 \mathrm{~d}$ of storage and, later SSC : TA ratio increased with increased stor-
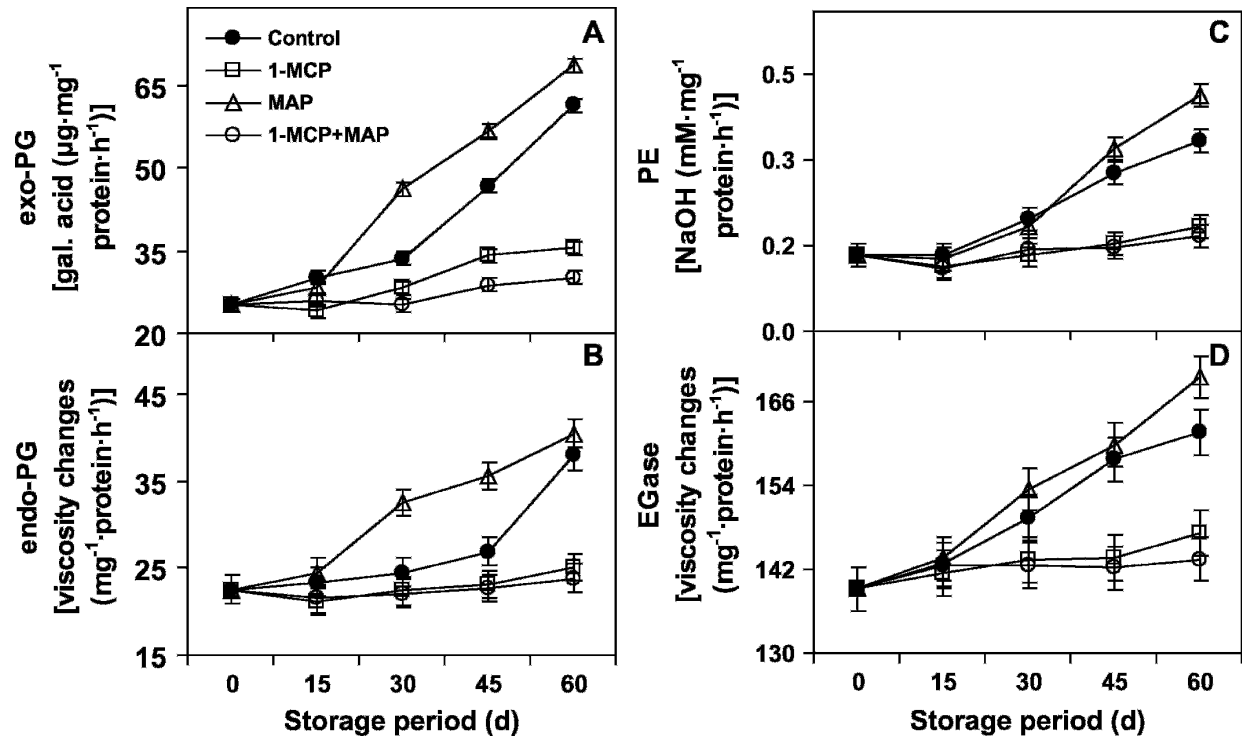

Fig. 6. Effects of postharvest application of 1-methylcyclopropene (1-MCP) and modified atmosphere packaging (MAP) alone or in combination $(+)$ on $(\mathbf{A})$ activities of exo-polygalacturonase (exo-PG), (B) endopolygalacturonase (endo-PG), (C) pectin esterase (PE), and (D) endo-1,4- $\beta$-D-glucanase (EGase) enzymes during low-temperature storage in pulp tissues of 'Tegan Blue' japanese plum ( $\mathrm{n}=3$, three replications). Vertical bars represent SE. Least significant difference (LSD) $(P \leq 0.05)$ for exo-PG: treatments $(\mathrm{T})=1.39$, storage period $(\mathrm{SP})=1.55, \mathrm{~T} \times \mathrm{SP}=3.1$. $\mathrm{LSD}(P \leq 0.05)$ for endo-PG: $\mathrm{T}=2.1, \mathrm{SP}=2.32, \mathrm{~T} \times \mathrm{SP}=4.63 . \mathrm{LSD}(P \leq 0.05)$ for $\mathrm{PE}: \mathrm{T}$ $=0.01, \mathrm{SP}=0.01, \mathrm{~T} \times \mathrm{SP}=0.03 . \mathrm{LSD}(P \leq 0.05)$ for $\mathrm{EGase}: \mathrm{T}=7.7, \mathrm{SP}=8.6, \mathrm{~T} \times \mathrm{SP}=17.4$. age period (Fig. 9C). On day 60, fruit stored in MAP showed highest SSC : TA ratio $(34) \approx 43 \%, 57 \%$, and $56 \%$ higher as compared with control and 1-MCP-treated fruit stored either in MAP or in normal atmosphere, respectively. Ripe fruit stored for 5 and 7 weeks in MAP exhibited significantly $(P \leq 0.05)$ lower SSC (11\% and $9.9 \%)$ as compared with all other treatments (Fig. 10A). Similarly, MAP fruit showed significantly $(P \leq 0.05)$ lower TA $(0.41 \%$ and $0.19 \%$ ) in fully ripe fruit after 5 and 7 weeks of storage as compared with other treatments (Fig. 10B). 1MCP-treated fruit maintained TA at a higher level in ripe fruit after 5 and 7 weeks of storage than control and fruit stored in MAP. SSC:TA ratio of fruit stored in MAP was higher after 5 and 7 weeks of low-temperature storage (Fig. 10C).

Fruit COLOR. Fruit stored in MAP at the fully ripe stage after 5 and 7 weeks of storage exhibited 


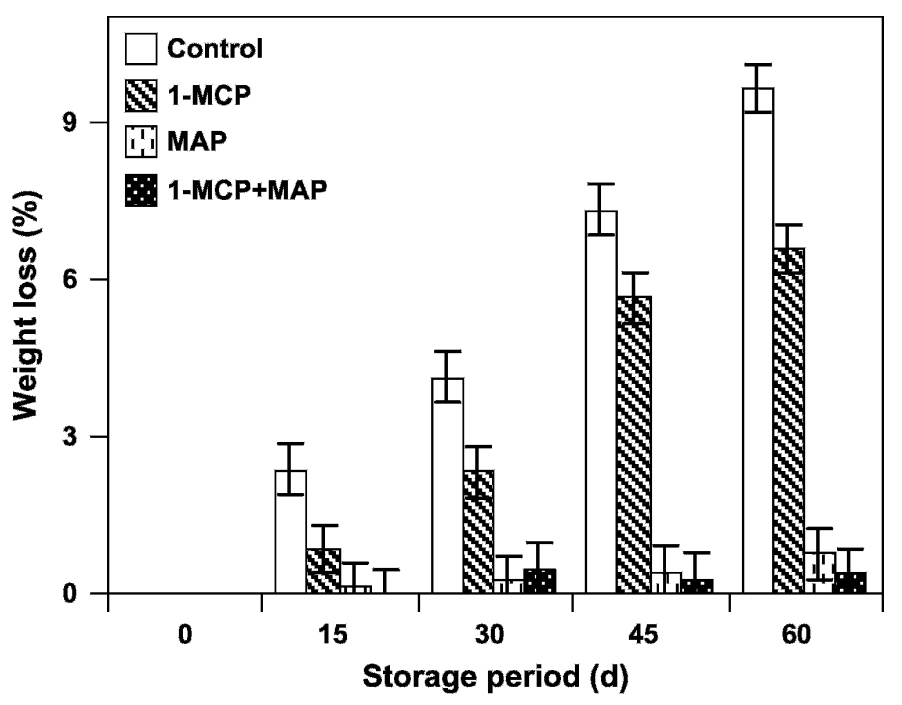

Fig. 7. Effects of postharvest application of 1-methylcyclopropene (1-MCP) and modified atmosphere packaging (MAP) alone or in combination $(+)$ on weight loss during low temperature storage in 'Tegan Blue' japanese plum $(n=3$, three replications). Vertical bars represent SE. Least significant difference $(P \leq 0.05)$ for weight loss: treatments $(\mathrm{T})=0.61$, storage period $(\mathrm{SP})=0.69$, $\mathrm{T} \times \mathrm{SP}=1.37$.

lowest chromaticity value $L^{*}$ of fruit skin as compared with other treatments (Fig. 11A). A similar trend in chromaticity value $L^{*}$ for fruit pulp was observed in fully ripe fruit after 5 and 7 weeks of storage, whereas MAP fruit showed lowest pulp $\mathrm{L}^{*}$ value as compared with other treatments (Fig. 11D). 1MCP-treated ripe fruit after 5 and 7 weeks of storage exhibited higher chroma value of fruit skin compared with other treatments (Fig. 11B). Chroma value of pulp tissues was reduced in MAP fruit, whereas control and 1-MCP-treated fruit did not show any significant difference in pulp chroma value at the fully ripe stage after 5 and 7 weeks of storage (Fig. 11E). Fruit stored with MAP bags exhibited reduced hue angle at the fully ripe stage as compared with other treatments (Fig. 11C). Similarly, hue angle of pulp tissues was low in fruit that were stored in MAP than other treatments (Fig. 11F).

Ascorbic ACID AND total ANTIOxidants. During low-temperature storage, the level of ascorbic acid in all treatments decreased with increase in the storage period (Fig. 12A). Fruit stored in MAP exhibited a continuous decrease in level of total antioxidants, and on day 60 of storage, these fruit showed $24 \%$, $27 \%$, and $17 \%$ reduction in the level of total antioxidants as compared with control and 1-MCP-treated fruit stored either in MAP or in normal atmosphere, respectively (Fig. 12B). After 5 and 7 weeks of low-temperature storage and fruit ripening, ascorbic acid level of control and 1-MCP-treated fruit pulp tissues was significantly higher as compared with fruit stored in MAP (Fig. 13A). Pulp of 1-MCP-traeated fruit exhibited 5\%, $13 \%$, and $26 \%$ higher level of total antioxidants in contrast to control and fruit stored in MAP either with or without 1-MCP treatment, respectively (Fig. 13B).

\section{Discussion}

During cold storage as well as during fruit ripening, fruit stored in MAP showed a rapid increase in respiration rate than other treatments. In the present study, the rate of respiration was determined as $\mathrm{CO}_{2}$ production by the fruit itself, whereas in

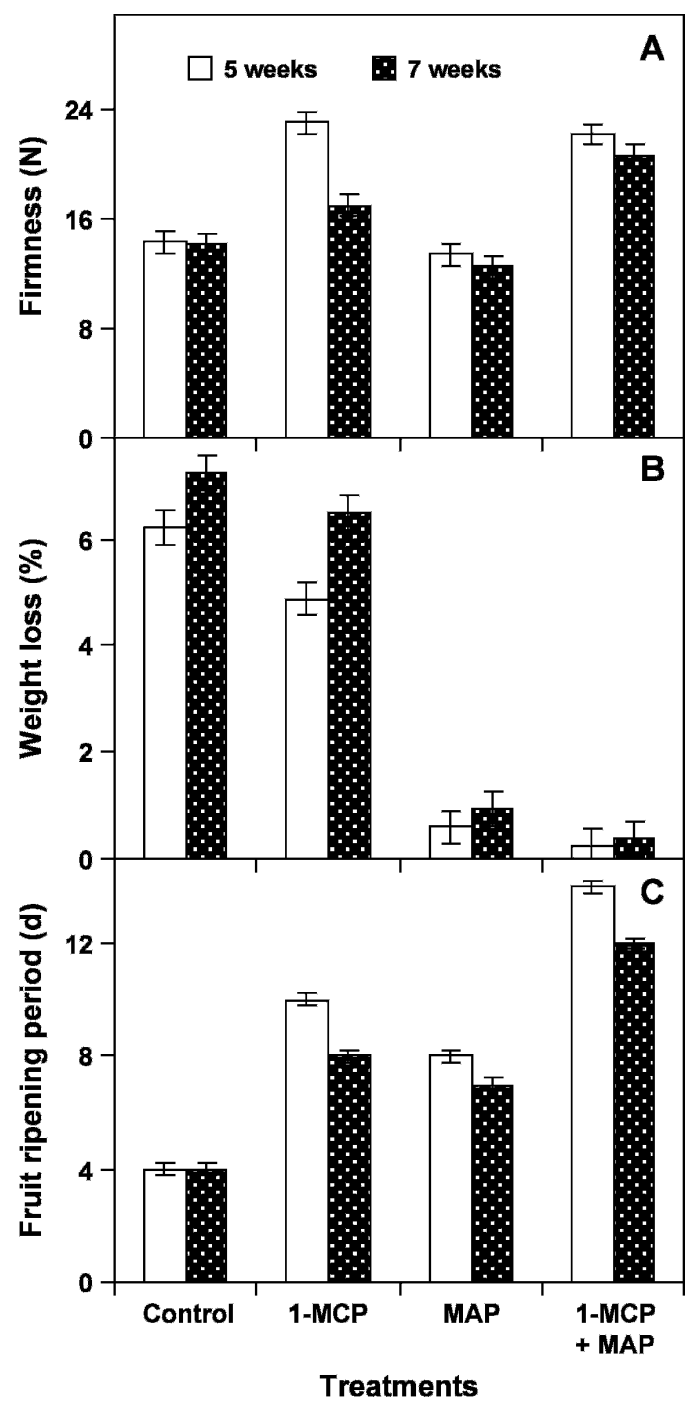

Fig. 8. Effects of postharvest application of 1-methylcyclopropene (1-MCP) and modified atmosphere packaging (MAP) alone or in combination $(+)$ on $(\mathbf{A})$ fruit firmness, (B) weight loss, and $(\mathbf{C})$ fruit ripening period in 'Tegan Blue' japanese plum stored for 5 and 7 weeks $(n=18$, three replications, six fruit per replication for fruit firmness; $n=3$, three replications for fruit ripening period and weight loss). Vertical bars represent SE. Least significant difference (LSD) $(P \leq 0.05)$ for fruit firmness: treatments $(\mathrm{T})=1.89$, storage period $(\mathrm{SP})=1.33, \mathrm{~T} \times \mathrm{SP}=2.67 . \mathrm{LSD}(P \leq 0.05)$ for weight loss: $\mathrm{T}=0.67, \mathrm{SP}=0.48$, $\mathrm{T} \times \mathrm{SP}=0.95 . \mathrm{LSD}(P \leq 0.05)$ for fruit ripening period: $\mathrm{T}=0.52, \mathrm{SP}=0.51$, $\mathrm{T} \times \mathrm{SP}=0.62$.

other studies, the changes in the in-package gas concentrations have been monitored and higher $\mathrm{CO}_{2}$ and lower $\mathrm{O}_{2}$ levels have been found within MAP around the fruit commodities (Ding et al., 2002; Meir et al., 1997; Pesis et al., 2000). Higher respiration rate of fruit stored in MAP may be the result of lower $\mathrm{O}_{2}$ levels inside the bags creating anoxic conditions that switched on the anaerobic respiration during storage and as well as during fruit ripening. Similarly, Jayas and Jeyamkondan, (2002) reported that reduced $\mathrm{O}_{2}$ levels in the MA retard the overall metabolic activities and extend the storage life. Oxygen levels below the threshold limit have been reported to initiate anaerobic respiration with production of acetaldehyde, ethanol, lactates, and off-flavors in fruit with unacceptable eating quality (Pesis et al., 2002). In fermentative metabolism without uptake of $\mathrm{O}_{2}$, ethanol production involves the decarboxylation 


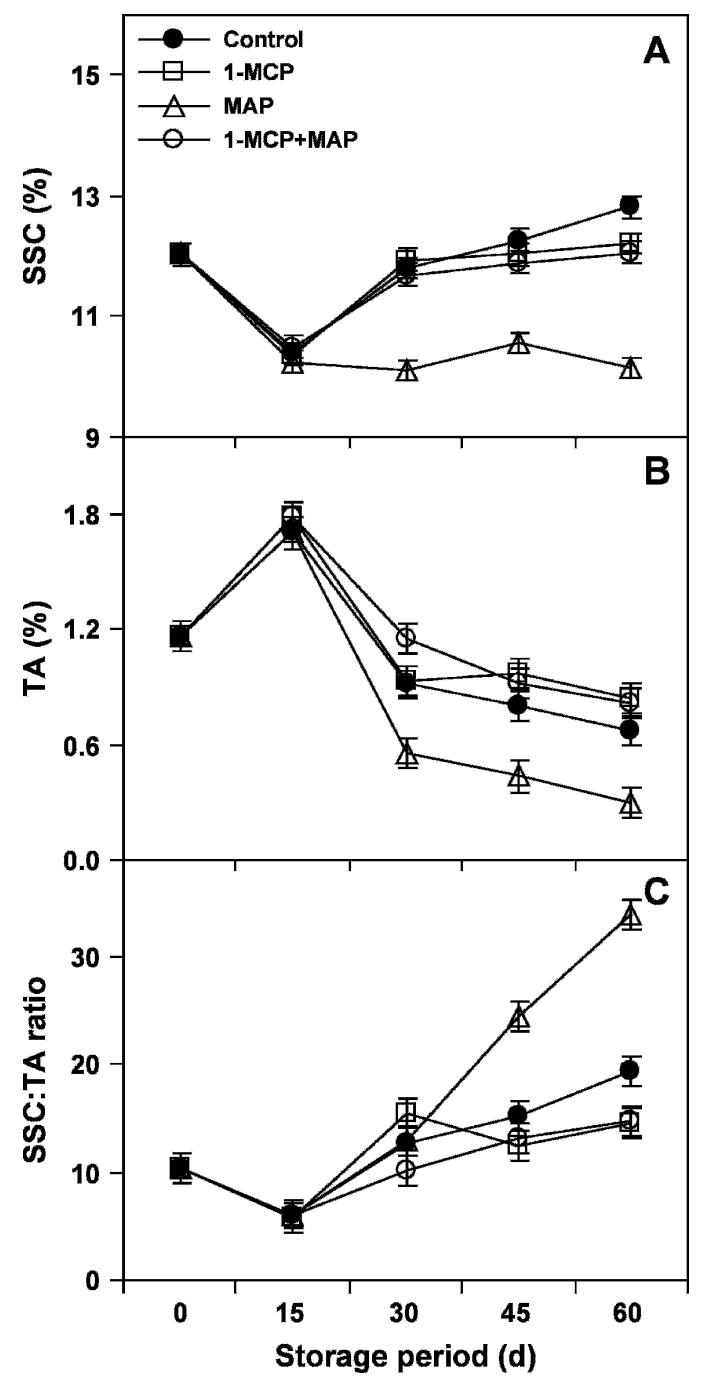

Fig. 9. Effects of postharvest application of 1-methylcyclopropene (1-MCP) and modified atmosphere packaging (MAP) alone or in combination $(+)$ on $(\mathbf{A})$ soluble solids concentration (SSC), (B) titratable acidity (TA), and (C) SSC : TA ratio during low-temperature storage in 'Tegan Blue' japanese plum ( $\mathrm{n}=3$, three replications). Vertical bars represent SE. Least significant difference (LSD) $(P \leq 0.05)$ for SSC: treatments $(\mathrm{T})=0.23$, storage period $(\mathrm{SP})=0.26, \mathrm{~T} \times \mathrm{SP}=0.52 . \mathrm{LSD}(P \leq 0.05)$ for $\mathrm{TA}: \mathrm{T}=0.08, \mathrm{SP}=0.09, \mathrm{~T} \times \mathrm{SP}=$ 0.18 . $\mathrm{LSD}(P \leq 0.05)$ for $\mathrm{SSC}: \mathrm{TA}$ ratio: $\mathrm{T}=1.75, \mathrm{SP}=1.96, \mathrm{~T} \times \mathrm{SP}=3.9$.

of pyruvate to $\mathrm{CO}_{2}$ (Fonseca et al., 2002). Stimulated respiration rates have also been observed in lemon (Citrus limon Burm.), lettuce (Lactuca sativa L.), eggplant (Solanum melongena $\mathrm{L}$.), cucumber (Cucumis sativus L.), and potato (Solanum tuberosum L.) exposed to $\mathrm{CO}_{2}$-enriched environments (Fonseca et al., 2002).

The reduction in ethylene production in 1-MCP-treated fruit is ascribed to irreversible blocking of the ethylene-binding site (Sisler and Serek, 1997) and reduction in the activities of ethylene biosynthesis enzymes (Khan and Singh, 2007). Similarly, during low-temperature storage, 1-MCP treated fruit resulted in reduced endogenous ethylene production in some japanese plum and european plum cultivars (Khan and Singh, 2004; Valero et al., 2005). A MA richer in $\mathrm{CO}_{2}$ and poorer in $\mathrm{O}_{2}$ can potentially reduce ethylene sensitivity and production in fruit and vegetable crops (Kader et al., 1989). Reduced ethylene production of fruit stored in MAP bags may be the result of a

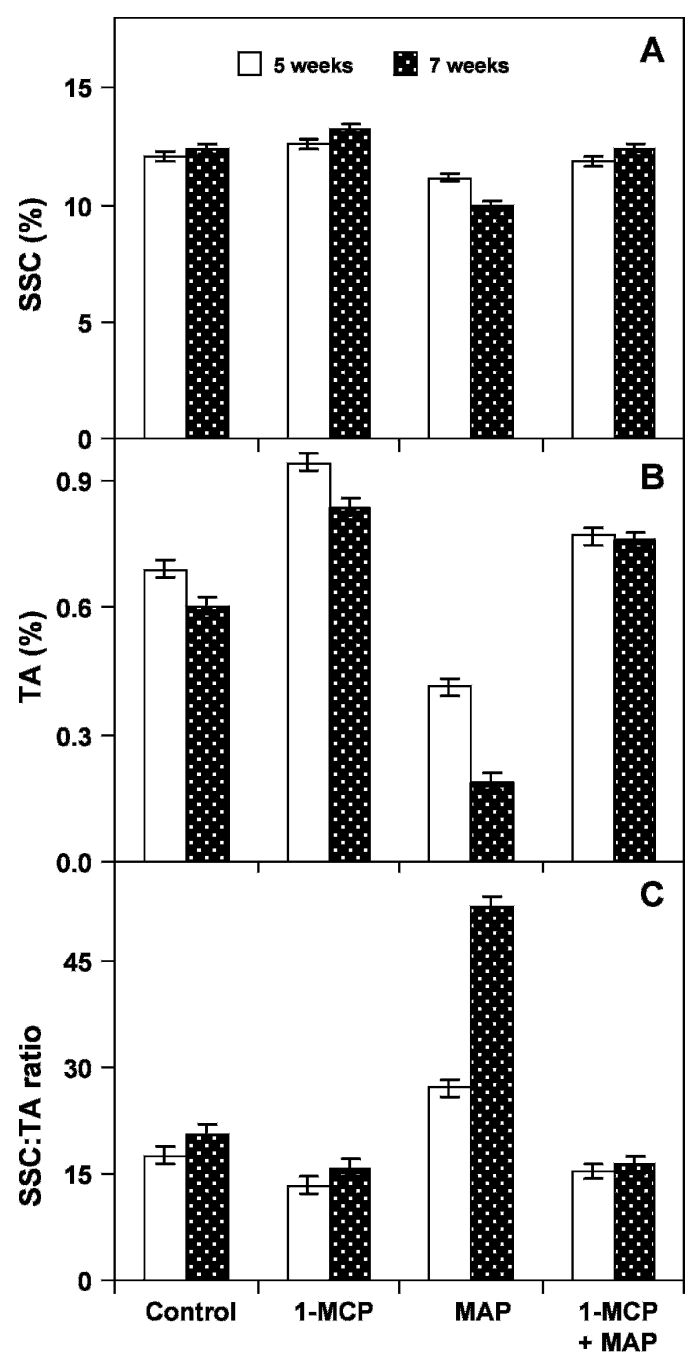

Treatments

Fig. 10. Effects of postharvest application of 1-methylcyclopropene (1-MCP) and modified atmosphere packaging (MAP) alone or in combination $(+)$ on (A) soluble solids concentration (SSC), (B) titratable acidity (TA), and (C) SSC : TA ratio in 'Tegan Blue' japanese plum stored for 5 and 7 weeks $(n=3$, three replications). Vertical bars represent SE. Least significant difference (LSD) $(P \leq 0.05)$ for SSC: treatments $(\mathrm{T})=0.13$, storage period $(\mathrm{SP})=$ nonsignificant, $\mathrm{T} \times \mathrm{SP}=0.2$. LSD $(P \leq 0.05)$ for $\mathrm{TA}: \mathrm{T}=0.04, \mathrm{SP}=0.03$, $\mathrm{T} \times \mathrm{SP}=0.06 . \mathrm{LSD}(P \leq 0.05)$ for SSC:TA ratio: $\mathrm{T}=2.5, \mathrm{SP}=1.76, \mathrm{~T} \times \mathrm{SP}=$ 3.52 .

higher concentration of $\mathrm{CO}_{2}$ inside the bag because $\mathrm{CO}_{2}$ has been reported to have an antagonistic effect on ethylene biosynthesis (Jayas and Jeyamkondan, 2002). During MA storage, similar reduction in ethylene production has been reported in avocado (Persea americana Mill), banana (Musa sp. group AAA subgroup Cavendish cv. Williams), and european plum (Jiang et al., 1999; Ke et al., 1991; Meir et al., 1997). However, during fruit ripening after 7 weeks of storage, an increased rate of ethylene production in fruit stored in MAP as compared with 1-MCP-treated fruit stored either with or without MAP could also be the result of accumulation of ethylene precursor in fruit stored in polyethylene bags during MA storage, and therefore when products are transferred to normal air, ethylene is produced rapidly (Wang, 1990). 1-MCP and MAP application to japanese plum fruit significantly $(P \leq$ 0.05 ) reduced the activities of ACS and ACO enzymes and as 


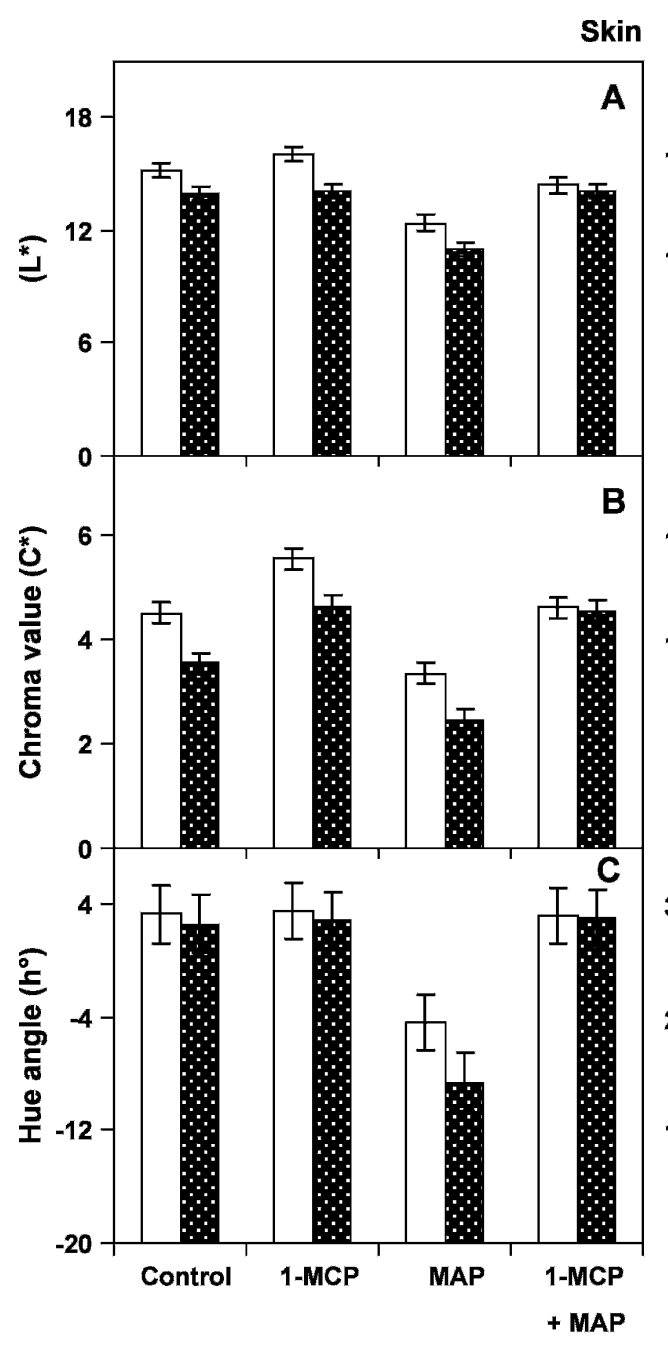

Treatments

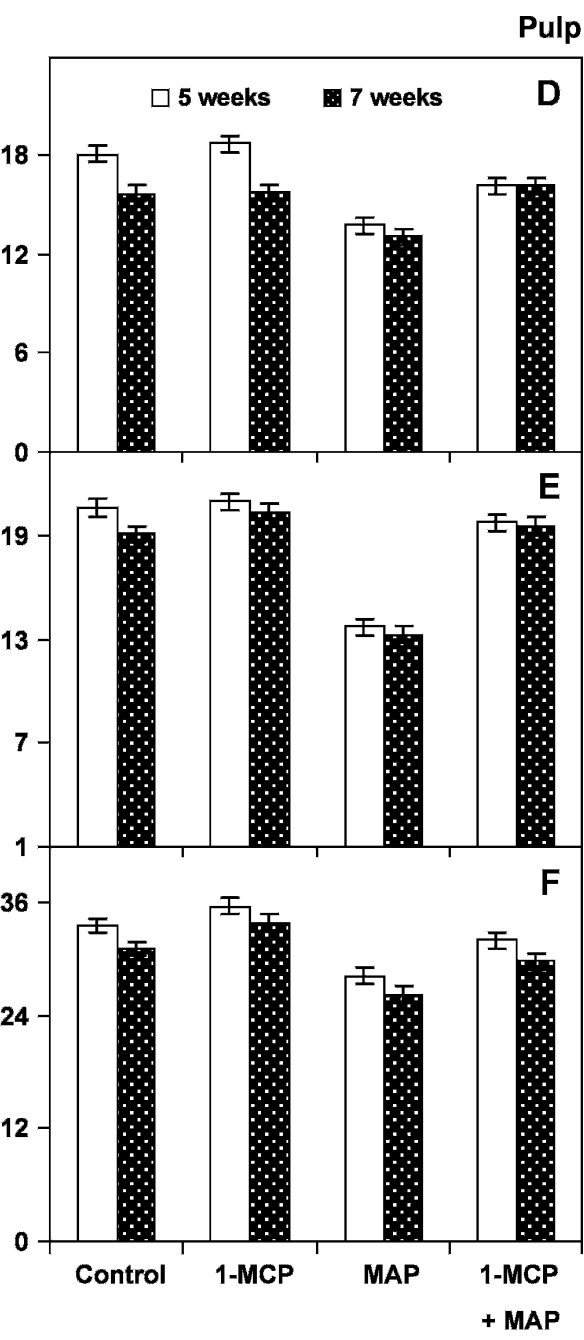

Treatments

Fig. 11. Effects of postharvest application of 1-methylcyclopropene (1-MCP) and modified atmosphere packaging (MAP) alone or in combination $(+)$ on chromaticity values $\mathrm{L}^{*}$, chroma value, and hue angle of fruit skin $(\mathbf{A}, \mathbf{B}$, and $\mathbf{C})$, and pulp (D, E, and $\mathbf{F})$ in 'Tegan Blue' japanese plum stored for 5 and 7 weeks ( $\mathrm{n}=18$, three replications, six fruit per replication). Vertical bars represent SE. Least significant difference (LSD) $(P \leq 0.05)$ for skin $L^{*}$ : treatments $(\mathrm{T})=0.87$, storage period $(\mathrm{SP})=0.62, \mathrm{~T} \times \mathrm{SP}=1.24$. LSD $(P \leq 0.05)$ for skin chroma value: $\mathrm{T}=0.62$, $\mathrm{SP}=0.44, \mathrm{~T} \times \mathrm{SP}=0.88 . \mathrm{LSD}(P \leq 0.05)$ for skin hue angle: $\mathrm{T}=5.57, \mathrm{SP}=3.93, \mathrm{~T} \times \mathrm{SP}=7.88 . \mathrm{LSD}(P \leq 0.05)$ for Pulp $\mathrm{L}^{*}: \mathrm{T}=1.04, \mathrm{SP}=0.74, \mathrm{~T} \times \mathrm{SP}=1.47 . \mathrm{LSD}(P \leq 0.05)$ for pulp chroma value: $\mathrm{T}=1.12, \mathrm{SP}=$ nonsignificant, $\mathrm{T} \times \mathrm{SP}=1.59 . \mathrm{LSD}(P \leq 0.05)$ for pulp hue angle: $\mathrm{T}=1.8, \mathrm{SP}=1.28, \mathrm{~T} \times \mathrm{SP}=2.56$.

well as ACC content during storage and during fruit ripening. Reduced activities of ACS and ACO enzymes have been reported in 1-MCP-treated japanese plum fruit (Khan and Singh, 2007). A significant reduction in ethylene biosynthesis and activities of ACS, ACO enzymes, and their respective transcripts has also been reported in 1-MCP-treated apple (Malus $\times$ domestica Borkh.) fruit (Dal Cin et al., 2006). The reduction in the ACC content in pulp tissues may be ascribed to the reduction in the activities of ACS enzymes during storage or conversion of ACC to malonyl or glutamylamino derivatives instead of ethylene production (Lelievre et al., 1997). The mechanism through which MAP reduces the activities of ACS and ACO enzymes and ACC content in japanese plum and european plum is yet not well understood and warrants further investigations.

The reduction in japanese plum fruit softening with 1-MCP treatment may be attributed to reduction in ethylene production with application of 1-MCP (Figs. 1A and 3) and consequent reduction in the fruit softening (Khan and Singh, 2007). Similarly, reduction in fruit softening with 1-MCP application has also been reported in some japanese plum and european plum cultivars (Khan and Singh, 2004; Valero et al., 2005). Fruit stored in MAP without 1-MCP application softened similar to those without treatment. Reduction in the activities of these enzymes with 1-MCP application may be the result of reduction in the endogenous ethylene production with 1-MCP treatment because ethylene has been reported to regulate the transcription of several ripening-related genes, including those related to fruit softening (Alexander and Grierson, 2002). Similarly, 1MCP application has been reported to reduce the activities of fruit softening enzymes such exo-PG, endoPG, PE, and EGase in japanese plum (Khan and Singh, 2007). Fruit stored in MAP alone also showed reduction in the activities of exo-PG, endo-PG, $\mathrm{PE}$, and EGase enzymes as compared with control fruit. However, reduction in these enzymes in a MAP bag was not as pronounced as observed in 1-MCP-treated fruit stored in MAP (Fig. 6). In papaya, MA storage retarded the decrease in the fruit firmness and reduced the activities of PG, PE, and cellulase enzymes (Lazan et al., 1993).

Reduction in weight loss is one of the major advantages of MAP resulting from water vapor accumulation with in the bags and increase in the RH. A sevenfold reduction in weight loss has been reported in japanese plum stored in polyethylene packaging as compared with unwrapped fruit (Kluge et al., 1999). Reduction in weight loss has also been observed in loquat (Eriobotrya japonica Lindl.) and peach packed in MAP compared with control fruit (Ding et al., 2002; FernandezTrujillo et al., 1998). Application of 1-MCP in combination with MAP delayed the fruit ripening up to $10 \mathrm{~d}$ than other treatments (Fig. 8C). In banana and mango, application of 1MCP in combination with the use of polyethylene bags has been reported to extend postharvest life (Jiang and Joyce, 2000; Jiang et al., 1999). Use of MAP has also been reported to extend the storage period in peach and european plum (Fernandez-Trujillo et al., 1998; Turk and Ozkurt, 1994).

During cold storage (Fig. 9) and after storage in ripe fruit (Fig. 10), lower SSC and TA were observed in fruit stored in MAP as compared with 1-MCP-treated and control fruit, which suggests that during storage and ripening, organic acids and sugar became the substrates for a higher rate of anaerobic 


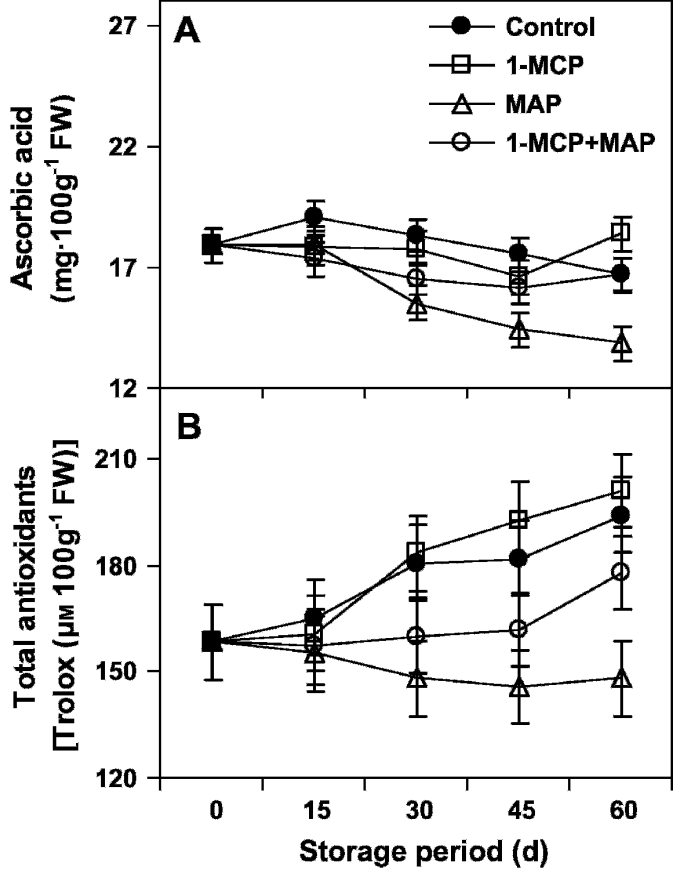

Fig. 12. Effects of postharvest application of 1-methylcyclopropene (1-MCP) and modified atmosphere packaging (MAP) alone or in combination $(+)$ on (A) ascorbic acid and (B) total antioxidants during low-temperature storage in pulp tissues of 'Tegan Blue' japanese plum $(n=3$, three replications). Vertical bars represent SE. Least significant difference (LSD) $(P \leq 0.05)$ for ascorbic acid: treatments $(\mathrm{T})=0.76$, storage period $(\mathrm{SP})=0.85, \mathrm{~T} \times \mathrm{SP}=1.71$. LSD $(P \leq 0.05)$ for total antioxidants: $\mathrm{T}=13.5, \mathrm{SP}=15.1, \mathrm{~T} \times \mathrm{SP}=30.2$.

respiration (Lurie, 1992) observed during low-temperature storage and during fruit ripening after storage (Figs. 1A and 2). Under elevated $\mathrm{CO}_{2}$ concentrations in the MAP, the reduction in malic acid, the main acid in japanese plum, may be associated with inhibition of succinic acid dehydrogenase in Krebs cycle (Wankier et al., 1970). Higher SSC : TA ratio in fruit stored in MAP may be result of very low TA.

No significant differences were observed between ripe control fruit and fruit treated with 1-MCP and stored either in a normal atmosphere or in MAP for chromaticity value $\mathrm{L}^{*}$, chroma value, and hue angle of fruit skin and pulp tissues (Fig. 11), which suggests that with these treatments, japanese plum storage and shelf life can be extended without any adverse effects on fruit skin and pulp color. Lower value of color parameters of ripe fruit stored in MAP bags revealed that after storage, these fruit exhibited fast ripening in contrast to 1-MCPtreated fruit. Similarly, storage atmosphere with higher $\mathrm{CO}_{2}$ and lower $\mathrm{O}_{2}$ reduced the $\mathrm{L}^{*}$, chroma value, and hue angle in sweet cherry fruit as compared with fruit stored in air (Remon et al., 2004).

The reduction in the level of ascorbic acid may be the result of delayed biosynthesis or fast degradation of ascorbic acid in MAP fruit. An earlier reduced level of ascorbic acid has been reported in polypropylene and Pebax-C (Atofina, Tokyo) -packed papaya fruit as compared with low-density polyethylene-packed or unpacked fruit (Singh and Rao, 2005). There is very little information available regarding the effects of MAP on total antioxidant levels in general and particularly in japanese plum and european plum. The reduction in the level

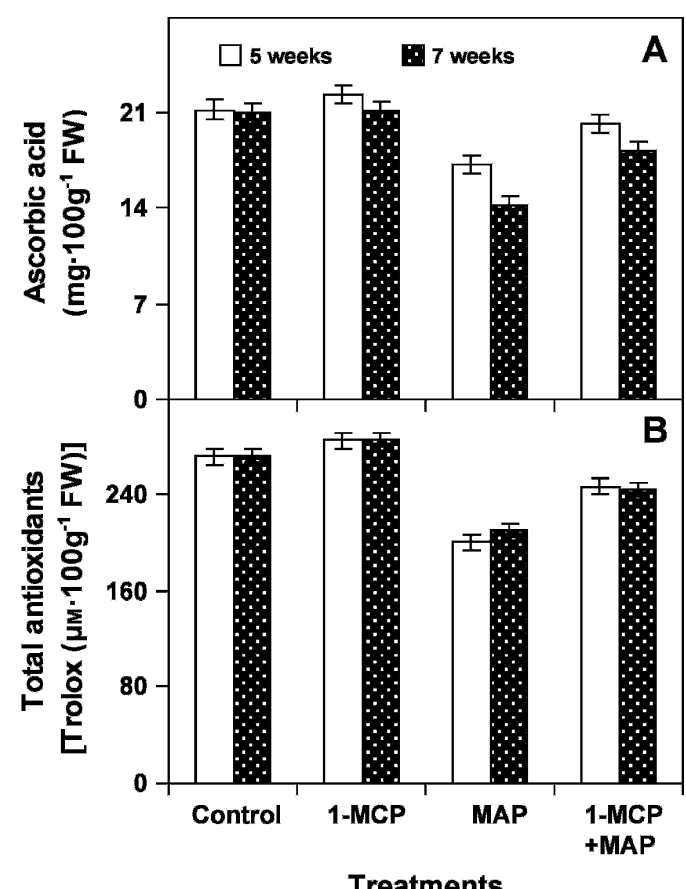

Fig. 13. Effects of postharvest application of 1-methylcyclopropene (1-MCP) and modified atmosphere packaging (MAP) alone or in combination $(+)$ on (A) ascorbic acid and (B) total antioxidants in 'Tegan Blue' japanese plum stored for 5 and 7 weeks $(n=3$, three replications). Vertical bars represent SE. Least significant difference (LSD) $(P \leq 0.05)$ for ascorbic acid: treatments $(\mathrm{T})$ $=1.47$, storage period $(\mathrm{SP})=1.04, \mathrm{~T} \times \mathrm{SP}=2.09$. LSD $(P \leq 0.05)$ for total antioxidants: $\mathrm{T}=13.5, \mathrm{SP}=$ nonsignificant $(\mathrm{NS}), \mathrm{T} \times \mathrm{SP}=\mathrm{NS}$.

of total antioxidants in fruit stored in MAP may be the result of increased activities of cytochrome oxidase, ascorbic acid oxidase, and peroxidase enzymes (Rocha et al., 1995). No significant changes in level of total antioxidants were reported in pomegranate stored in MAP (Lopez-Rubira et al., 2005). The changes in level of total antioxidants in fruit stored in MAP warrant further investigations.

In conclusion, treatment of fruit with $1-\mathrm{MCP}\left(1.0 \mu \mathrm{L} \cdot \mathrm{L}^{-1}\right)$ and storage in MAP inhibited the ethylene biosynthesis and fruit softening with substantial reduction in weight loss during low-temperature storage. This treatment can be used effectively to extend the storage life of japanese plum up to 7 weeks at $0 \pm 1$ ${ }^{\circ} \mathrm{C}$ and $90 \% \pm 5 \% \mathrm{RH}$ followed by 8 -d ripening at $20 \pm 1{ }^{\circ} \mathrm{C}$ without any adverse effects on quality of ripe fruit.

\section{Literature cited}

Abdi, N., W.B. McGlasson, P. Holford, M. Williams, and Y. Mizrahi. 1998. Responses of climacteric and suppressed-climacteric plums to treatment with propylene and 1-methylcyclopropene. Postharvest Biol. Technol. 14:29-39.

Alexander, L. and D. Grierson. 2002. Ethylene biosynthesis and action in tomato: A model for climacteric fruit ripening. J. Expt. Bot. 53:2039-2055.

Blankenship, S.M. and J.M. Dole. 2003. 1-methylcyclopropene: A review. Postharvest Biol. Technol. 28:1-25.

Bradford, M.M. 1976. A rapid and sensitive method for the quantitation of microgram quantities of protein utilizing the principles of protein-dye binding. Anal. Biochem. 72:248-254.

Brand-Williams, W., M.E. Cuvelier, and C. Berset. 1995. Use of a free radical method to evaluate antioxidant activity. LebensmittelWissenschaft und -Technologie 28:25-30. 
Chin, L.H., Z.M. Ali, and H. Lazan. 1999. Cell wall modifications, degrading enzymes and softening of carambola fruit during ripening. J. Expt. Bot. 50:767-775.

Dal Cin, V., F.M. Rizzini, A. Botton, and P. Tonutti. 2006. The ethylene biosynthetic and signal transduction pathways are differently affected by 1-MCP in apple and peach fruit. Postharvest Biol. Technol. 42:125-133.

Ding, C.K., K. Chachin, Y. Ueda, Y. Imahori, and C.Y. Wang. 2002. Modified atmosphere packaging maintains postharvest quality of loquat fruit. Postharvest Biol. Technol. 24:341-348.

Fernandez-Trujillo, J.P., J.A. Martinez, and F. Artes. 1998. Modified atmosphere packaging affects the incidence of cold storage disorders and keeps 'Flat' peach quality. Food Res. Intl. 31:571-579.

Fischer, R.L. and A.B. Bennett. 1991. Role of cell wall hydrolysis in fruit ripening. Annu. Rev. Plant Physiol. Plant Mol. Biol. 42:675-703.

Fonseca, S.C., F.A.R. Oliveira, and J.K. Brecht. 2002. Modelling respiration rate of fresh fruits and vegetables for modified atmosphere packages: A review. J. Food Eng. 52:99-119.

Huang, D., B. Ou, and R.L. Prior. 2005. The chemistry behind antioxidant capacity assays. J. Agr. Food Chem. 53:1841-1856.

Jayas, D.S. and S. Jeyamkondan. 2002. Postharvest technology: Modified atmosphere storage of grains, meats, fruits and vegetables. Biosystems Eng. 82:235-251.

Jiang, Y. and D.C. Joyce. 2000. Effects of 1-methylcyclopropene and in combination with polyethylene bags on the postharvest life of mango fruit. Ann. Appl. Biol. 137:321-327.

Jiang, Y., D.C. Joyce, and A.J. Macnish. 1999. Extension of the shelf life of banana fruit by 1-methylcyclopropene in combination with polyethylene bags. Postharvest Biol. Technol. 16:187-193.

Jobling, J., R. Pradhan, S.C. Morris, L. Mitchell, and A.C. Rath. 2003. The effect of ReTain plant growth regulator [aminoethoxyvinylglycine (AVG)] on the postharvest storage life of 'Tegan Blue' plums. Austral. J. Expt. Agr. 43:515-518.

Kader, A.A., D. Zagory, and E.L. Kerbel. 1989. Modified atmosphere packaging of fruits and vegetables. Crit. Rev. Food Sci. Nutr. 28:1-30.

Ke, D., L. Rodriguez-Sinobas, and A.A. Kader. 1991. Physiology and prediction of fruit tolerance to low oxygen atmosphere. J. Amer. Soc. Hort. Sci. 166:253-260.

Khan, A.S. and Z. Singh. 2004. Postharvest application of 1-MCP affects ethylene biosynthesis and firmness of 'Tegan Blue' plum. Acta Hort. 687:409-410.

Khan, A.S. and Z. Singh. 2007. 1-MCP regulates ethylene biosynthesis and fruit softening during ripening of 'Tegan Blue' plum. Postharvest Biol. Technol. 43:298-306.

Kluge, R.A., A.B. Bilhalva, and R.F.F. Cantillano. 1999. Influence of ripening stage and polyethylene packaging on cold storage of plum. Pesquisa Agropecuária Brasileira 34:323-329.

Lalel, H.J.D., Z. Singh, and S.C. Tan. 2003. The role of ethylene in mango fruit aroma volatiles biosynthesis. J. Hort. Sci. Biotechnol. 78:485-496.

Latifah, M.N., Z.M. Ali, and H. Lazan. 1997. Effects of modified atmosphere packaging on the quality of Eksotika papaya stored at low temperature. J. Trop. Agr. Food Sci. 25:95-102.

Lazan, H., Z.M. Ali, and M.K. Selamat. 1993. The underlying biochemistry of the effects of modified atmosphere and storage temperature on firmness decrease in papaya. Acta Hort. 343:141-147. Lelievre, J.M., A. Latche, B. Jones, M. Bouzayen, and J.C. Pech. 1997. Ethylene and fruit ripening. Physiol. Plant. 101:727-739.

Lopez-Rubira, V., A. Conesa, A. Allende, and F. Artes. 2005. Shelf life and overall quality of minimally processed pomegranate arils modified atmosphere packaged and treated with UV-C. Postharvest Biol. Technol. 37:174-185.

Lurie, S. 1992. Controlled atmosphere storage to decrease physiological disorders in nectarines. Int. J. Food Sci. Technol. 27:507-514.

Malik, A.U. and Z. Singh. 2005. Pre-storage application of polyamines improves shelf-life and fruit quality in mango. J. Hort. Sci. Biotechnol. 80:363-369.
McGuire, R.G. 1992. Reporting of objective color measurements. HortScience 27:254-255.

Meir, S., D. Naiman, M. Akerman, J.Y. Hyman, G. Zauberman, and Y. Fuchs. 1997. Prolonged storage of 'Hass' avocado fruit using modified atmosphere packaging. Postharvest Biol. Technol. 12: 51-60.

Navarro, M.L., M.B. Perez-Gago, and M.A. d. Rio. 2005. Effect of hydroxypropyl methylcellulose-beeswax edible composite coatings on 'Angeleno' plum quality during storage. Acta Hort. 682:10891096.

Pesis, E., D. Aharoni, Z. Aharon, R. Ben-Arie, N. Aharoni, and Y. Fuchs. 2000. Modified atmosphere and modified humidity packaging alleviates chilling injury symptoms in mango fruit. Postharvest Biol. Technol. 19:93-101.

Pesis, E., O. Dvir, O. Feygenberg, R.B. Arie, M. Ackerman, and A. Lichter. 2002. Production of acetaldehyde and ethanol during maturation and modified atmosphere storage of litchi fruit. Postharvest Biol. Technol. 26:157-165.

Petracek, P.D., D.W. Joles, A. Shirazi, and A.C. Cameron. 2002. Modified atmosphere packaging of sweet cherry (Prunus avium L., cv. 'Sams') fruit: Metabolic responses to oxygen, carbon dioxide, and temperature. Postharvest Biol. Technol. 24:259-270.

Plich, H., P. Wojcik, M. Tagliavini, M. Toselli, L. Bertschinger, P. Brown, D. Neilsen, and M. Thalheimer. 2002. The effect of calcium and boron foliar application on postharvest plum fruit quality. Acta Hort. 594:445-451.

Remon, S., A. Ferrer, P. Lopez-Buesa, and R. Oria. 2004. Atmosphere composition effects on Burlat cherry colour during cold storage. J. Sci. Food Agr. 84:140-146.

Robertson, J.A., F.I. Merredith, and B.G. Lyon. 1991. Effect of cold storage on the quality characteristics of 'Au-Rubrum' plums. J. Food Qual. 14:107-117.

Rocha, A.M.C.N., C.M. Brochado, R. Kirby, and M.M.B. Morais. 1995. Shelf life of chilled cut orange determined by sensory quality. Food Contr. 6:317-322.

Serrano, M., D. Martinez-Romero, S. Castillo, F. Guillen, and D. Valero. 2004. Role of calcium and heat treatments in alleviating physiological changes induced by mechanical damage in plum. Postharvest Biol. Technol. 34:155-167.

Serrano, M., D. Martinez-Romero, F. Guillen, and D. Valero. 2003. Effect of exogenous putrescine on improving shelf life of four plum cultivars. Postharvest Biol. Technol. 30:259-271.

Singh, S.P. and D.V.S. Rao. 2005. Effect of modified atmosphere packaging (MAP) on the alleviation of chilling injury and dietary antioxidants levels in 'Solo' papaya during low temperature storage. European J. Hort. Sci. 70:246-252.

Sisler, E.C. and M. Serek. 1997. Inhibitors of ethylene responses in plants at the receptor level: Recent developments. Physiol. Plant. 100: 577-582.

Turk, R. and A.S. Ozkurt. 1994. The storage of some stone fruits in modified atmosphere. Acta Hort. 368:850-855.

Valero, D., F. Guillen, J.M. Valverde, D. Martinez-Romero, S. Castillo, and M. Serrano. 2005. 1-MCP use on Prunus spp. to maintain fruit quality and to extend shelf life during storage: A comparative study. Acta Hort. 682:933-940.

Wang, C.Y. 1990. Physiological and biochemical effects of controlled atmopshere on fruits and vegetable, p. 197-224. In: Calderon, M. and R. Barkai-Golan (eds.). Food preservation by modified atmosphere. CRC Press, Boca Raton, FL.

Wang, L. and S. Vestrheim. 2003. Controlled atmosphere storage of Norwegian grown plums (Prunus domestica L.). Acta Agr. Scandinavica Sec. B-Soil Plant Sci. 53:33-37.

Wankier, B.N., D.K. Salunkhe, and W.F. Campbell. 1970. Effects of controlled atmosphere storage on biochemical changes in apricot and peach fruit. J. Amer. Soc. Hort. Sci. 95:604-609.

Watkins, C.B. 2006. The use of 1-methylcyclopropene (1-MCP) on fruits and vegetables. Biotechnol. Adv. 24:389-409. 